九州大学学術情報リポジトリ

Kyushu University Institutional Repository

Tubular Photobioreactor: A Preliminary

Experiment Using Synechococcus sp.

(Cyanobacteria) Cultivated in NPK Media for Biomass Production as Biofuel Feedstock

Ardiansyah, Sulthan Rafi i

Department of Biology, Universitas Indonesia

Orlando, Aliff Muhammad

Department of Biology, Universitas Indonesia

Rahman, Arif

Department of Mechanical Engineering, Universitas Indonesia

Prihantini, Nining Betawati

Department of Biology, Universitas Indonesia

他

https://doi.org/10.5109/2321011

出版情報 : Evergreen. 6 (2)，pp.157-161，2019-06. 九州大学グリーンテクノロジー研究教育センター バージョン：

権利関係 : 


\title{
Tubular Photobioreactor: A Preliminary Experiment Using Synechococcus sp. (Cyanobacteria) Cultivated in NPK Media for Biomass Production as Biofuel Feedstock
}

\author{
Sulthan Rafii Ardiansyah ${ }^{1}$, Aliff Muhammad Orlando ${ }^{1}$, Arif Rahman ${ }^{2}$, \\ Nining Betawati Prihantini ${ }^{1, *}$, and Nasruddin ${ }^{2}$ \\ ${ }^{1}$ Department of Biology, Universitas Indonesia, Kampus UI Depok 16424 Indonesia \\ ${ }^{2}$ Department of Mechanical Engineering, Universitas Indonesia, Kampus UI Depok 16424 Indonesia
}

*Author to whom correspondence should be addressed,
E-mail: nining.prihantini@gmail.com

(Received March 4, 2019, year; accepted March 26, 2019).

\begin{abstract}
Photobioreactor $(\mathrm{PBr})$ is a system that usually used for producing high amount of biomass. This system was designed for supplying multiple factor that providing a good biological condition for growth of the microalgae contained in the system. This research used Synechococcus sp. HS-9, an indigenous cyanobacteria isolated from Rawa Danau hot spring, Banten. This strain was selected because their ability to adapt and reproduce. Synechococcus sp. HS-9 was inoculated into two units of tubular photobioreactor ( $\mathrm{tPBr}$ ) along with NPK medium and then observed using turbidimeter. This strain of cyanobacteria is grown up to $4.44 \times 10^{6}$ cells $/ \mathrm{mL}$ (tPBr-1) and $4.29 \times 10^{6}$ cells $/ \mathrm{mL}$ (tPBr-2) (cell number) or 56.5 NTU (tPBr-1) and 55.9 NTU (turbidity) after eleven days. The results showed that combination of NPK media, $\mathrm{tPBr}$ system, and Synechococcus sp. HS-9 are producing potential biomass for biofuel feedstock. This research also proved that use of NPK media as growth medium are promising, because of the good efficiency of cost production.
\end{abstract}

Keywords: Tubular, Photobioreactor, Synechococcus sp., NPK, Biofuel.

\section{Introduction}

The need of energy for life is one of many problems that humankind cannot be avoided. Human are using certain amount of energy sources such as fossil fuel and electricity. Nowadays, crisis of energy is starting to approach human life. In example, Japan has been the third largest energy consumer country in the world with 461 MTOE (Million Tonnes of Oil Equivalent) primary energy consuming per year ${ }^{1)}$. To maintain energy, many researchers had been trying using many components to made alternative fuels ${ }^{2,3}$. One type of alternative fuel is biofuel ${ }^{4}$. This kind of fuel can be obtained from many bioresources such as plants and microorganisms ${ }^{5}$. Cyanobacteria, a member of microalgae, is potential bioresources for producing biofue $\mathrm{l}^{6}$. This happen because their photosynthetic ability and their biomolecules that very similar to plants. In other perspective, use of cyanobacteria are very promising because of their fast growth ability ${ }^{7}$.

To increase the microalgae doubling processes, many researchers and industrial factory are using photobioreactor $(\mathrm{PBr})$ system to support the cyanobacteria growth factor ${ }^{8}$. There are two main type of $\mathrm{PBr}$ system, open pond $\mathrm{PBr}$ system and closed $\mathrm{PBr}$ system. Closed $\mathrm{PBr}$ system can be divided by their shape, i.e. flat panel $\mathrm{PBr}$ and tubular PBr. For many years, tubular $\mathrm{PBr}$ system are known for producing biomass effectively ${ }^{9}$. Some research showed that this type of $\mathrm{PBr}$ system are good for green algae (chlorophytes) and blue-green algae (cyanobacteria).

Microalgae also needs nutrients to grow, beside the system and another environment factors. The growth media is the critical point for producing cyanobacterial biomass ${ }^{10)}$. There are many types of growth media that can be used for cultivating cyanobacteria, for example BlueGreen 11 (BG-11), Bold's Basal Medium (BBM) and Cyanobacteria-TAPS $(\mathrm{CT})^{11)}$. Nevertheless, these growth mediums are expensive in cost, because of the using of many types of pure inorganic compounds. Those mediums are effectively used for laboratory scale culture, not for the industrial scale ${ }^{12}$. Many industrial factories are searching and using alternative media for producing more costefficient biomass. By using Synechococcus sp. HS-9 (indigenous cyanobacteria isolated from Rawa Danau, Banten ${ }^{13)}$ this research aim is to observe the growth Synechococcus sp. HS-9 inside the tubular photobioreactor system (tPBr) along with NPK as growth media. This research also conducted to measure costefficiency of NPK media compared to other general laboratory growth media. 


\section{Methods}

There are some stages in this research, first is the assembly of $\mathrm{tPBr}$ system. There are two units of $\mathrm{tPBr}$ system. This system is assembled using custom made acrylic tubes and some aquarium components. All the components are assembled according to the design shown in fig. 1. After the $\mathrm{PBr}$ system are assembled, all units are placed in controlled area to reducing unnecessary factor that can affect the results.

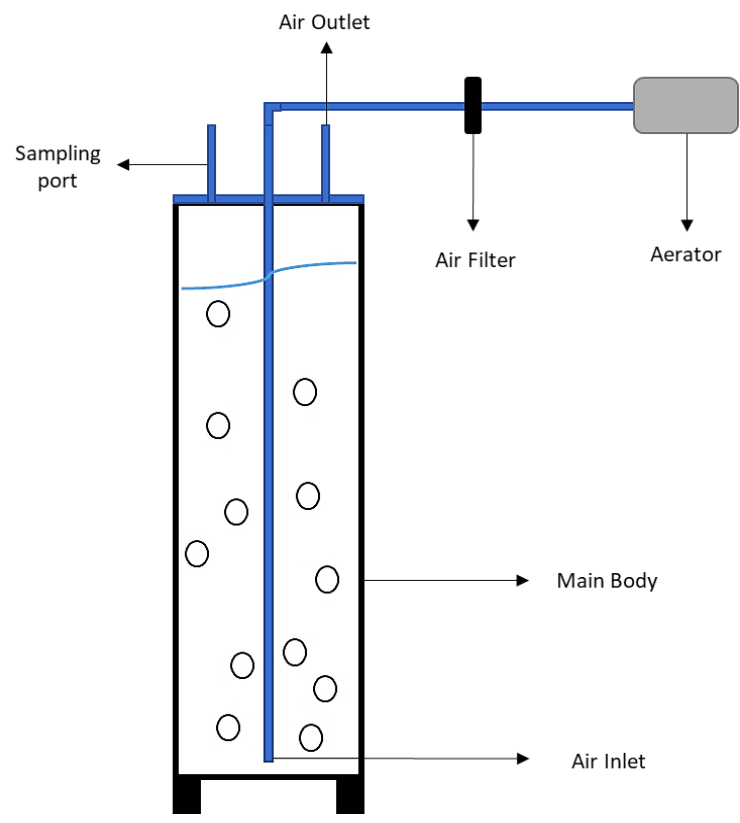

Fig. 1: Schematic of Tubular Photobioreactor System $(\mathrm{tPBr})$

Optical density methods were chosen, to calculate the biomass growth ${ }^{14)}$. Standard curve of biomass optical density was acquired by using serial dilution methods. This stage resulting a standard curve and an equation. This curve and equation later used as a standard to daily measurement and data collecting. The curve and equation are shown in fig. 2.

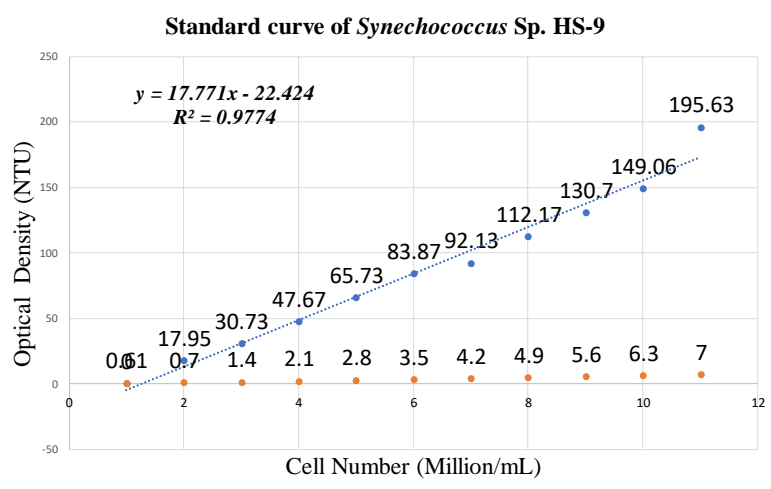

Fig. 2: Standard Curve of Synechococcus sp. HS-9
The next step is inoculation process, which some amounts of inoculums are pour into growth medium. Media that used for this experiment is made by dissolving $320 \mathrm{mg}$ of Grow More ${ }^{\mathrm{TM}}$ NPK fertilizer into four (4) liters of distilled water and then sterilized by using autoclave, which have $80 \mathrm{ppm}$ of final concentration. Synechococcus sp. HS-9 inoculum is inoculated into $\mathrm{tPBr}$ system with 1:10 ratio (200 mL biomass of Synechococcus sp. HS-9 into $1800 \mathrm{~mL}$ medium $)^{15}$. The $\mathrm{tPBr}$ that now contain microalgae culture was placed in controlled room which have 15000 lux light intensity and constant $27^{\circ} \mathrm{C}$ temperature. Data observations are done by collecting turbidity data using turbidimeter ${ }^{16)}$. Results from turbidimeter (NTU/Nephelometric Turbidity Unit) are transformed into cell number using the equation from standard curve.

\section{Experimental Results}

\subsection{Growth Measurement of Synechococcus sp. HS-9 Biomass}

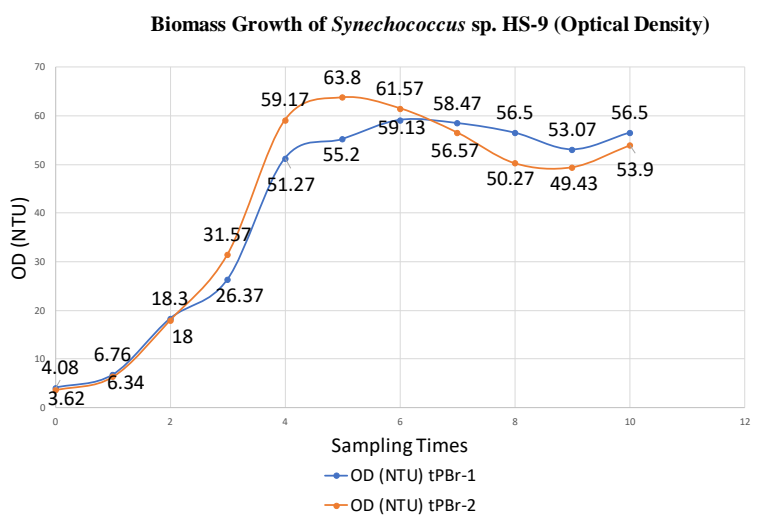

Fig. 3: Biomass Growth of Synechococcus sp. HS-9 (Optical Density)

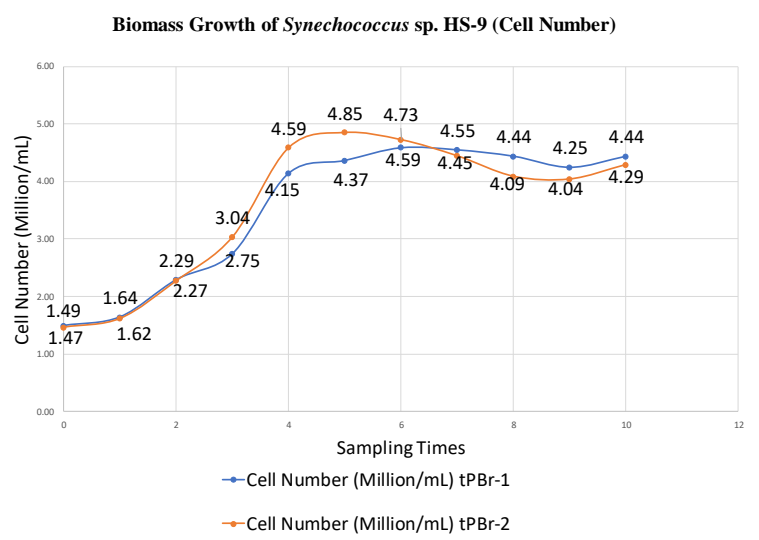

Fig. 4: Biomass Growth of Synechococcus sp. HS-9 (Cell Number) 
The growth of Synechococcus sp. HS-9 were observed for 11 days, data shown an increasing trend for Synechococcus sp. HS-9 biomass. The cell numbers on the last days of observations are $56.5 \mathrm{NTU}$ or $4.44 \times 10^{6}$ cells $/ \mathrm{mL}$ for tPBr-1 and $55.9 \mathrm{NTU}$ or $4.29 \times 10^{6}$ cells $/ \mathrm{mL}$ for $\mathrm{tPBr}-2$. The graphic shown that biomass of Synechococcus sp. HS-9 are significantly increased, start from day $2\left(\mathrm{~T}_{1}\right)$ until day $5\left(\mathrm{~T}_{4}\right)$ in both $\mathrm{PBr}$ system. After showing an increase trend, the graphic enters stationery phase. This phenomenon showed from day $6\left(\mathrm{~T}_{5}\right)$ until the end of data collecting period. This is caused by decreased nutrients level inside the medium.

The nutrients inside the medium are used by the cell for metabolism and other living processes. After the cell reach the carrying capacity of medium, the cell will enter the stationery phases and will not increase further ${ }^{17)}$.

According to the equation.1, the rate of growth for Synechococcus sp. HS-9 can be calculated by using the formula. Letter $r$ is symbol for rate of growth. The equation can be solved by knowing cell number in the beginning $(\mathrm{No})$, cell number at the end of period $(\mathrm{Nt})$, and interval of the period $(\Delta t)^{11)}$. The equations are showed in equation 1 .

$$
r=\frac{\ln \frac{(N t)}{(N o)}}{\Delta t}=\frac{\ln N t-\ln N o}{\Delta t}
$$

Equation. 1: Equation for Measuring Rate of Growth

$$
\begin{aligned}
r_{t P B r-1}= & \frac{\ln \left(\frac{4.44 \times 10^{6}}{1.49 \times 10^{6}}\right)}{10}=0.108 / \text { day } \\
r_{t P B r-2}= & \frac{\ln \left(\frac{4.29 \times 10^{6}}{1,47 \times 10^{6}}\right)}{10}=0.106 / \text { day }
\end{aligned}
$$

Equation. 2: Rate of Growth Equation for Synechococcus sp. HS-9 in Tubular Photobioreactor System

From the equations.2, the rate of Synechococcus sp. HS9 biomass growth is 0.108 / day for tPBr- 1 and $0.106 /$ day for $\mathrm{tPBr}-2$. This result is not significantly different from each unit. Even though the growth rate of Synechococcus sp. HS-9 in NPK media are showing increase trend. The rate of growth still can be enhanced by increasing the media concentration.

Other factor that contributed in Synechococcus sp. HS9 biomass growth are air flow and nutrient distribution inside the $\mathrm{tPBr}$ system. Since it has tubular shape, the flow of air and medium inside the system are patterned like fig. 5. This pattern of flow made every single cell inside the system get adequate nutrients and light for its metabolism $^{18)}$.

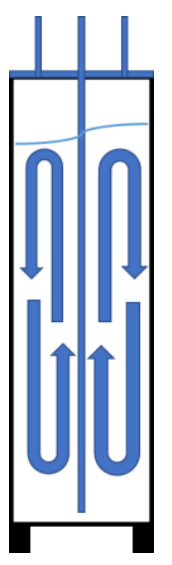

Fig. 5: Flow Pattern in $\mathrm{tPBr}$ System

\subsection{Macroscopic and Microscopic Observation of Synechococcus sp. HS-9 Biomass}

Macroscopic observation was done by taking a photo of $\mathrm{PBr}$ on first day of observation (t0), four (t5), and seven (t8) to acquire colour change. The colours of Synechococcus sp. HS-9 biomass are changing from grey green ( $\mathrm{t} 0)$, moss green (t5) and light green (t8). Change in colour of microalgae culture are indicating the growth of microalgae ${ }^{19)}$ which cultured on $\mathrm{PBr}$. With the changing of the colour in every sampling day, the number of cells on the $\mathrm{PBr}$ system also increased, until it hits a peak and the colour will decrease and become fader.

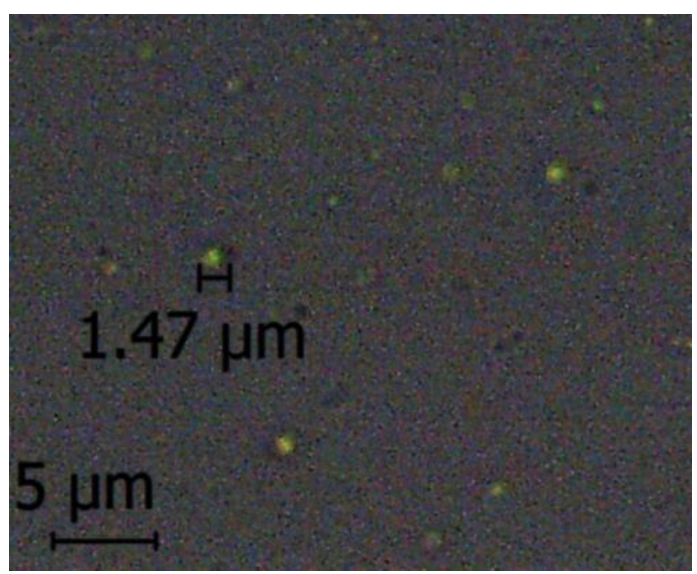

Fig. 6: Photomicrograph of Synechococcus sp. HS-9

On the last day, the microalgae under the microscope to see and calculate the size of the microalgae that had been cultured on the $\mathrm{PBr}$ system and collect microscopic data. Synechococcus sp. are 0.8 to 1.5 microns $(\mu \mathrm{m})$ in size ${ }^{20)}$. From fig.6, Synechococcus sp. HS-9 seems to have more 
rounded-shape cell. This could happen because Synechococcus as a microorganism, responds to its surrounding environment ${ }^{21)}$. Shape of microorganism are designed based on how they regulate their metabolism and how effective it was $^{22}$.

\subsection{NPK Fertilizer as Photobioreactor Media}

Based on previous research, NPK media can be used as growth media in $\mathrm{PBr}$ system ${ }^{23)}$. Even though the results are lower from Bold's Basal Media, use of this media can be more profitable than other growth media. From chemical perspective, NPK fertilizer that were used for making NPK growth media are consisted from several nutrients such as Nitrogen $(\mathrm{N})$, Phosphoric Acid $\left(\mathrm{P}_{2} \mathrm{O}_{5}\right)$, Soluble Potassium $\left(\mathrm{K}_{2} \mathrm{O}\right)$, and other micronutrients.

Meanwhile, Bold's Basal Media (BBM) is consisted of 16 nutrients consist of macronutrients and micronutrients ${ }^{24)}$. Nutrient composition in BBM are more promising for growing Synechococcus sp. greatly. It happens because, this media is providing all nutrients that needed for the metabolism. Although, not all components in it are utilized by related algae ${ }^{25}$.

Meanwhile on the economical perspective, use of NPK fertilizers as growth media is relatively cheap. One kilogram of Grow More ${ }^{\mathrm{TM}}$ NPK fertilizer cost around \$5 USD, and only used about $100 \mathrm{mg}$ to make one-liter media (100 ppm), which only cost for $\$ 0.0005$ USD/liter media. This fertilizer already contains all the required Nitrogen, Phosphor and Potassium. This is a very good cost for producing high amount of Synechococcus sp. biomass compared to cultivation using standard media that can be cost around \$1-10 USD/liter. Use of NPK media also more practical than standard growing media.

\section{Conclusion}

Biomass growth of Synechococcus sp. HS-9 in tubular photobioreactor are very potential to be used as biofuel feedstock. The biomasses are grown from 56.5 NTU or $4.44 \times 10^{6}$ cells $/ \mathrm{mL}$ for $\mathrm{tPBr}-1$ and $55.9 \mathrm{NTU}$ or $4.29 \times 10^{6}$ cells $/ \mathrm{mL}$ for $\mathrm{tPBr}-2$. This is happened because the cell got adequate nutrient flow inside the $\mathrm{PBr}$ system. This research also proven that NPK fertilizer can be used for Synechococcus sp. growing media. Use of NPK media also more economical and more practical for large scale cultivation. Even that good result, optimal concentration for long-lasting and high producing biomass growth media must be conducted in the recent future.

\section{Acknowledgements}

This research was funded by Hibah Publikasi Internasional Terindeks untuk Tugas Akhir Mahasiswa (Hibah PITTA) Tahun Anggaran 2018 to Nasruddin, grant no. 2498/UN2.R3.1/HKP.05.00/2018.

\section{References}

1) M. K. Barai \& B. B. Saha. Energy Security and Sustainability in Japan. EVERGREEN Joint Journal of Novel Carbon Resource Sciences \& Green Asia Strategy 2 (1). 49-56 (2015).

2) R. Slade \& A. Bauen. Micro-algae Cultivation for Biofuels: Cost, Energy Balance, Environtmental Impacts, and Future Prospect. Biomass \& Bioenergy 53. 29-38 (2013).

3) E. Kusrini, S. Harjanto. A. H. Yuwono. Applications of A Green Chemistry Design, A Clean Environment, and Bioenergy to Promote the Sustainability and Added Value of Products. International Journal of Technology 7. 4 (2015).

4) Y. Chen, J. Ma, B. Han, P. Zhang, H. Hua, H. Chen, $\mathrm{X}$. Su, Emissions of automobiles fueled with alternative fuels based on engine technology: A review. Journal of Traffic and Transportation Engineering (English Edition) 5 (4). 318-334. (2018)

5) M. Hj. Hassan \& Md. A. Kalam. An Overview of Biofuel as a Renewable Energy Source: Development and Challenges. Procedia Engineering 56. 39-53. (2013)

6) J. Milano, H. C. Ong, H. H. Masjuki, W. T. Chong, M. K. Lam, P. K. Loh, V. Vellayan. Microalgae Biofuels as an Alternative to Fossil Fuel for Power Generation. Renewable and Sustainable Energy Review 58. 180-197 (2016).

7) N. E. Nozzi, J. W. K. Oliver, S. Atsumi. Cyanobacteria as a Platform for Biofuel Production. Frontiers in Bioengineering and Biotechnology 1 (7). 1-6. (2013)

8) J. Yu, M. Liberton, P. F. Cliften, R. D. Head, J. M. Jacobs, R. D. Smith, D. W. Koppenaal, J. J. Brand, H. B. Pakrasi. Synechococcus elongatus UTEX 2937, A Fast-Growing Cyanobacterial Chassis for Biosynthesis Using Light and CO2. Scientific Reports 8132. 1-10 (2015).

9) E. Molina, J. Fernandez, F. G. Acien, Y. Chisti. Tubular Photobioreactor Design for Algal Cultures. Journal of Biotechnology 92. 113-131 (2001).

10) M. Borowitzka \& N. R. Moheimani. Algae for Biofuels and Energy Developments in Applied Phycology 5. Springer Sciences. Dodrecht, p. xii +285 (2013)

11) R. A. Andersen. Algal Culturing Techniques. Elsevier Academic Press. California, p. 589 (2005).

12) A. Illavarasi, D. Mubarakali, R. Praveenkumar, E. Baldev, N. Thajuddin. Optimization of Various 
Growth Media of Freshwater Microalgae for Biomass Production. Biotechnology 10 (6). 540-545. (2011)

13) N. B. Prihantini. Polyphasic Taxonomy of Culturable Cyanobacteria Isolated from Hot Springs in West Java, Indonesia. Dissertation Department of Biology, Faculty of Mathematics and Natural Sciences, Depok, p. 115. (2015).

14) L. Lu. G. Yang. B. Zhu. K. Pan. A comparative study on three quantitating methods of microalgal biomass. Indian Journal of Geo Marine Sciences 46 (11). 2265-2272 (2017).

15) S. R. Ardiansyah, A. M. Orlando, A. Rahman, N. B. Prihantini, Nasruddin. Effect of Aeration in Simple Photobioreactor System for Biomass Production of Synechococcus sp. (Cyanobacteria) HS-7 and HS-9 as Biofuel Feedstock. E3S Web of Conferences 67. 1-6. (2018)

16) N. S. Ferrando, H. H. Benitez, N. A. Gabellone, M. C. Claps, P. R. Altamirano. A Quick and Effective Estimation of Algal Density by Turbidimetry Developed with Chlorella vulgaris Cultures. Limnetica 34 (2). 397-406. (2015)

17) M. Madigan, J. Martino, K. Bender, D. Buckley, D. Stahl. Brock Biology of Microorganisms. $14^{\text {th }}$ ed. Pearson Education. United States of America, p. 1030. (2015)

18) N. C. Kommareddy \& V. V. Ananthula. CFD Simulation of Algae Production in Airlift Photobioreactor. Journal of Hazardous, Toxic, and Radioactive Waste 21 (4). 1-7. (2017)

19) M. Cordoba, M. A. Porta-Gándara. J. Gutierrez. Evaluation of Isochrysis Galbana (Clone T-ISO) Cell Numbers by Digital Image Analysis of Color Intensity. Journal of Applied Phycology 22. 427-434 (2010).

20) J. D. Wehr \& R. G. Sheath. Freshwater Algae of North America. Academic Press Publisher. California, p. xv + 897. (2003)

21) J. Jezberová \& J. Komárková. Morphometry and Growth of Three Synechococcus-like Picoplanktic Cyanobacteria at Different Culture Conditions. Hydrobiologia 578. 17-27. (2007)

22) K. D. Young. Bacterial Morphology: Why have Different Shapes. Current Opinion in Microbiology 10 (6). 596-600 (2007).

23) N. Rakhmayanti. Produksi Biomassa Leptolyngbya (Cyanobacteria) HS-16 Pada Medium BBM dan Medium NPK. Universitas Indonesia. 86 (2018).
24) NIES. NIES-Collection List of Strains $6^{\text {th }}$ edition Microalgae and Protozoa. National Institute of Environtmental Studies. Tsukuba, p. v + 159. (2000)

25) M. Jämsä, F. Lynch, A. Santana-Sánchez, P. Laaksonen, G. Zaitsev, A. Solovchenko, Y. Allahverdiyeva. Nutrient Removal and Biodiesel Feedstock Potential of Green Alga UHCC00027 Grown in Municipal Wastewater Under Nordic Conditions. Algal Research 26. 65-73. (2017) 